Available online on 15.09.2020 at http://jddtonline.info
Open Access to Pharmaceutical and Medical Research
unrestricted non-commercial use, provided the original work is properly cited

Open 2 Access

Research Article

\title{
Anti-Inflammatory Potential Evaluation (In-Vitro and In-Vivo) of Arthrophytum scoparium Aerial Part
}

\author{
Kaddour Sabrina Manel *, Arrar Lekhmici and Baghiani Abderrahmane * \\ Laboratory of Applied Biochemistry, Faculty of Nature and Life Sciences, Ferhat Abbas University of Setif, Setif 19000. Algeria
}

\begin{abstract}
Arthrophytum scoparium is plant commonly used in folk medicine in Algeria to treat numerous human diseases especially infectious, Rheumatism, diabetes and cancer. However, its anti-inflammatory activity and the underlying mechanisms have not been studied systematically. The present study aims to assess both the in vitro and in vivo anti-inflammatory potential and antioxidant activity of the plant. Results showed that $A$. scoparium chloroform extract (ChE) contains the largest amount of phenolic and flavonoid compounds. In-vitro bioassay consisted of investigating the effect of the plant extracts against protein denaturation (BSA and egg albumin). In-vivo anti-inflammatory activity was evaluated by measuring the percentage inhibition of carrageenan-induced rat paw edema after oral administration of the extracts. Results showed that inhibition of protein denaturation was maximum in case of $A$. scoparium crude extract (CrE) with dose dependant manner Similarly in the in-vivo study, carrageenan induced inflammation was significantly antagonized by $\mathrm{CrE}$ with inhibition of $87.02 \%$ at $400 \mathrm{mg} / \mathrm{kg}$. CrE extracts showed the highest scavenger effect against hydroxyl and hydrogen peroxide. The CrE showed potent anti-inflammatory activity in both the conditions in vivo and in vitro. In conclusion different $A$. scoparium extracts scavenged reactive oxygen species efficiently; it may be due to the presence of its flavonoids and polyphenols. These results support the traditional use of this plant.
\end{abstract}

Keywords: Arthrophytum scoparium, polyphenols, anti-inflammatory activity, radical scavenging activity.

Article Info: Received 17 July 2020; Review Completed 24 August 2020; Accepted 30 August 2020; Available online 15 September 2020

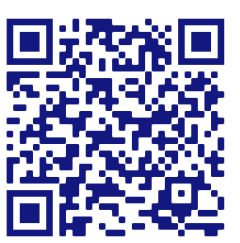

Cite this article as:

Kaddour SM, Arrar L, Baghiani A, Anti-Inflammatory Potential Evaluation (In-Vitro and In-Vivo) of Arthrophytum scoparium Aerial Part, Journal of Drug Delivery and Therapeutics. 2020; 10(5):213-218

http://dx.doi.org/10.22270/jddt.v10i5.4409

Kaddour Sabrina Manel, Laboratory of Applied Biochemistry, Faculty of Nature and Life Sciences, Ferhat Abbas University of Setif, Setif 19000. Algeria

Baghiani Abderrahmane, Laboratory of Applied Biochemistry, Faculty of Nature and Life Sciences, Ferhat Abbas University of Setif, Setif 19000. Algeria

\section{INTRODUCTION}

Inflammation is a host defence mechanism of the body and it's an essential immune response that enables the body to survival during infection or injury and maintains tissue homeostasis in noxious conditions ${ }^{1}$ (Chen et al., 2017). But in some conditions when negative effect of the inflammatory process is produced example: rheumatoid arthritis, osteoarthritis, inflammatory bowel diseases, retinitis, multiple sclerosis, psoriasis and atherosclerosis ${ }^{2}$ (Poovizhi et al., 2019). For overcoming this problem, search of newer drugs is very requisite and necessary and there are many of phytoconstituents present in plants which are playing a very important role in the treatment of inflammation ${ }^{3}$ (Yuan et al., 2016). For a long time, plants have been a major source of pharmacologically-active substances. Plant extracts possess various biological compounds and have been used commonly for the treatment of inflammatory diseases ${ }^{4}$ (Che and Zhang, 2019). In a recent study, the anti-inflammatory activity of several plant extracts was demonstrated scientifically 5 (Bailey-Shaw et al., 2017). Therefore, various plant-derived remedies have recently received great interest because of their diverse bioactive constituents and relatively low toxicity in the treatment of various medical conditions, including inflammation-related ailments ${ }^{6}$ (Oguntibeju, 2018).

Arthrophytum scoparium belongs to the family of chenopodiaceae. It was worldwide distributed, especially in desert and semi desert areas. A.scoparium is a local medicinal plant, which has been used extensively in the southwestern part of Algeria. It is used to treat numerous human diseases especially infectious (skin infections, urinary and genital infections), Rheumatism, diabetes, cancer, infertility, hair problems and stomach disorder 7,8 (Allaoui et al., 2016; Fatehi et al., 2017).

CODEN (USA): JDDTAO 
This study aim to ascertain the anti-inflammatory properties of A.scoparium extracts against protein denaturation, and in an animal model of inflammation. In order to valorized the traditional use of this plant from one hand and from another hand to look for a new treatment, which may be used as alternative to the known pharmaceutical medicine already used in treating inflammation.

\section{MATERIALS AND METHODS}

\section{Plant collection}

The vegetal material was collected in April 2016 from ouled djellal, Biskra, Algeria and was identified by Pr. Oujhih B. an expert taxonomist at the Institut of nutrition and agronomy, university of Batna (Algeria), where a voucher specimen (227/ISVSA/ DA/UHLB1/17) was deposited. Plant materials were then washed separately with fresh water to remove dirt and other contaminants, and were dried for two weeks in free air in dark room. The dried materials were ground into coarse powder by a grinding machine and the materials were stored at room temperature for future use.

\section{Preparation of the extracts}

The extraction was performed according to Madoui et al. (2018) ${ }^{9}$. About $100 \mathrm{~g}$ of powdered plant materials was taken in amber colored extraction bottles and soaked with $1 \mathrm{~L}$ of methanol- water $(85: 15 \mathrm{v} / \mathrm{v})$ and kept under agitation overnight at $4^{\circ} \mathrm{C}$ the resulting solution was filtered to obtain the first filtrate. This procedure was repeated on the residue using water-methanol $(50: 50 \mathrm{v} / \mathrm{v})$ under agitation for 4 hours to obtain the last filtrate. The extracts were filtered separately through a fresh cotton plug and finally with Whatman No.1 filter papers. The filtrates were concentrated with a rotary evaporator under reduced pressure to get $\mathrm{CrE}$. The hydro-methanolic solution was washed with hexane several times until a clear upper layer of hexane was obtained. The lower layer was then extracted successively with chloroform and ethyl acetate to obtain 3 fractions; chloroform extract (ChE), ethyl acetate extract (EAE) and aqueous extract (AQE). Each fraction was stored at $-20 \stackrel{\circ}{\circ}$ until use.

\section{Determination of total phenolics}

Total phenolic contents in the extracts were determined by the modified Folin-Ciocalteu method described by Boussoualim et al.(2016) ${ }^{10}$. An aliquot of the extract was mixed with $0.5 \mathrm{ml}$ Folin-Ciocalteu reagent (previously diluted $1: 10 \mathrm{v} / \mathrm{v})$ and $0.4 \mathrm{ml}(75 \mathrm{~g} / \mathrm{L})$ of sodium carbonate. The tubes were vortexed for $15 \mathrm{~s}$ and allowed to stand for 1 $\mathrm{h}$ and $30 \mathrm{~min}$ at $25^{\circ} \mathrm{C}$ in the dark for color development. Absorbance was then measured at $760 \mathrm{~nm}$. Total phenolic contents were expressed in terms of gallic acid equivalent, GAE/g of dry extract. The experiment was repeated three times at each concentration.

\section{Determination of total flavonoids}

Total flavonoids were estimated using aluminum chloride colorimetric assay described by ${ }^{11}$ Guemmaz et al.(2018). To $1 \mathrm{ml}$ of samples/standard, $1 \mathrm{ml}$ of $2 \%$ aluminum chloride. The mixture left at room temperature for $10 \mathrm{~min}$. Absorbance of the mixtures was measured at $430 \mathrm{~nm}$. The flavonoids content was expressed in mg quercitin equivalent per gram of dry weight (QE). The experiment was repeated three times at each concentration.

\section{Determination of tannin content}

The capacity to precipitate hemoglobin was determined using bovine fresh blood according to Bouaziz et al12. Briefly, an equal volumes of each extract and hemolysed bovine blood (absorbance $=1.6$ ) were mixed. After $20 \mathrm{~min}$, the mixture was centrifuged at $4000 \mathrm{rpm}$ for $10 \mathrm{~min}$, and the absorbance of the supernatant was measured at $756 \mathrm{~nm}$. The results were expressed as mg equivalent tannic acid per gram dried weight (mg TAE/g DW).

\section{Hydroxyl radical scavenging activity}

Hydroxyl radical scavenging activity of the extractives was determined by the method of Mayouf et al.,(2019)13. Hydroxyl radical was generated by the $\mathrm{Fe}^{3+}$-ascorbateEDTA- $\mathrm{H}_{2} \mathrm{O}_{2}$ system (Fenton reaction). The assay is based on the production of $\mathrm{OH} \cdot$ in the reaction medium through the reaction of Fenton, then the $\mathrm{OH}$ product reacted with sodium salicylate to produce the hydroxyl salicylate complex. The reaction mixture $(3 \mathrm{ml})$ contained $1 \mathrm{ml}$ of $\mathrm{FeSO}_{4}(1.5 \mathrm{mM})$, $0.7 \mathrm{ml}$ of $\mathrm{H}_{2} \mathrm{O}_{2}(6 \mathrm{mM}), 0.3 \mathrm{ml}$ of sodium salicylate $(20 \mathrm{mM})$ and varying concentrations of plant extracts and standard. The mixtures were kept in a water bath at $37^{\circ} \mathrm{C}$ for $1 \mathrm{~h}$, after which the absorbance of the hydroxylated salicylate complex was measured at $562 \mathrm{~nm}$. The percentage of hydroxyl radical scavenging activity was calculated according to the following formula:

\section{Scavenging rate $\%=\left[1-\left(\mathrm{A}_{1}-\mathrm{A}_{2}\right) / \mathrm{A}_{0}\right]^{*} 100$}

Where, $A_{0}$ was the absorbance of the control (without sample) and $A_{1}$ was the absorbance in the presence of the sample; $A_{2}$ was the absorbance without sodium salicylate.

\section{Hydrogen peroxide scavenging activity}

Hydrogen peroxide is a weak oxidizing agent and can inactivate a few enzymes directly, usually by oxidation of essential thiol (-SH) groups. The hydrogen peroxide scavenging assay was carried out following the procedure mentioned by Benslama et al. (2019)14. For this aim, a solution of $\mathrm{H}_{2} \mathrm{O}_{2}(43 \mathrm{mM})$ was prepared in phosphate buffer (0.1 M, pH 7.4). The plant extracts at different concentrations in $3.4 \mathrm{ml}$ phosphate buffer was added to 0.6 $\mathrm{ml}$ of $\mathrm{H}_{2} \mathrm{O}_{2}$ solution $(43 \mathrm{mM})$. The absorbance value of the reaction mixture was recorded at $230 \mathrm{~nm}$. Blank solution was containing the sodium phosphate buffer without $\mathrm{H}_{2} \mathrm{O}_{2}$. The percentage of $\mathrm{H}_{2} \mathrm{O}_{2}$ scavenging activity of samples and standard compounds was calculated using the following equation:

$$
\mathrm{H}_{2} \mathrm{O}_{2} \text { scavenging effect } \%=\left(\mathrm{A}_{c}-\mathrm{A}_{\mathrm{s}}\right) / \mathrm{A}_{\mathrm{c}} * 100
$$

Where, $A_{C}$ is the absorbance of the control and $A_{S}$ is the absorbance in the presence of the sample or standards.

\section{Assessment of in vitro anti-inflammatory activity}

\section{Inhibition of albumin denaturation}

Anti-inflammatory activity of methanolic extracts of A.scoparium were studied according to the protocol of Rastogi et al. (2018), with some modifications ${ }^{15}$. Inhibition of albumin denaturation was done according to the protocol. The reaction mixture consists of an equal volume of test extracts of different concentrations and $1 \%$ aqueous solution of Bovine serum albumin (BSA or "Fraction V"). The $\mathrm{pH}$ of the reaction mixture was adjusted using a small amount of $1 \mathrm{~N} \mathrm{HCl}$. The sample extracts were incubated at $37^{\circ} \mathrm{C}$ for $20 \mathrm{~min}$ and then heated to $70^{\circ} \mathrm{C}$ for $5 \mathrm{~min}$. The absorbance was measured after cooling the samples at room temperature. The turbidity formed was measured at $660 \mathrm{~nm}$ using ultraviolet (UV)-visible spectrophotometer. The percentage inhibition of protein denaturation was calculated by using the following formula:

$\%$ inhibition of denaturation $=100 \times(1-\mathrm{A} 2 / \mathrm{A} 1)$ 
Where $\mathrm{A} 1=$ absorption of the control sample, and $\mathrm{A} 2=$ absorption of the test sample.

\section{Egg albumin denaturation}

Protein denaturation assay was done according to the method described by Kiranmayi et al. (2018) ${ }^{16}$. About $0.2 \mathrm{ml}$ of eggs albumin (from hen's egg) was comprised $5 \mathrm{ml}$ of reaction mixture, $2 \mathrm{ml}$ of varying concentrations of extract, and $2.8 \mathrm{ml}$ of phosphate-buffered saline (PBS, pH 6.4). The control was served as similar volume of double distilled water. Then, the mixture was heated at $70^{\circ} \mathrm{C}$ for $5 \mathrm{~min}$. After cooling, their absorbance was measured at $660 \mathrm{~nm}$ using pure blank. Aspirin was used as reference drug and treated as such for the determination of absorbance. The percentage inhibition of protein denaturation was calculated as below:

Percent inhibition $=[($ Abs control - Abs treated $) /$ Abs treated] $\times 100$.

\section{Carrageenan induced paw edema}

Antiinflammatory activity was determined in female wistar rats as described by Kim et al. (2018) ${ }^{17}$. This experiment involved five groups of five rats each, The experimental design was as follows: Group I: rats were orally administered with $1 \mathrm{ml} 0.9 \% \mathrm{NaCl}$ only (normal group); Group II: rats were orally administered with $10 \mathrm{mg} / \mathrm{kg}$ body weight (b.w.) diclofenac Sodium+ induction of inflammation using carrageenan (standard group); Group III, IV and V: rats were orally administered with 100,200 and $400 \mathrm{mg} / \mathrm{kg}$ b.w. $\mathrm{CrE}+$ induction of inflammation using carrageenan (test groups). Prior to the treatments, the initial paw edema of each rat was measured using a digital caliper. One hour after treatment, paw edema was induced by injecting $0.1 \mathrm{ml} 1 \%$ solution of carrageenan into the left hind paw just beneath the plantar of aponeurosis. Subsequently, the increase in left paw edema was measured at an hour interval for $6 \mathrm{~h}$ posttreatment. The percentage inhibition of inflammation was calculated as stated below:

$$
\% \text { inhibition of inflammation }=(1-\mathrm{Vt} / \mathrm{Vc}) \times 100
$$

$\mathrm{Vt}$ is the mean paw edema in the treated groups while Vt is the mean paw edema in the control group.

\section{Statistical analysis}

Data were expressed as mean \pm standard error of mean (SEM). Sample T-test analytical method was used to evaluate the difference between means in the in vitro experiments. Linear regression was performed to determine $50 \%$ inhibitory concentration (IC50). The difference between the experimental and control groups was determined using GraphPad Prism ${ }^{\circledR}$ version 5.0, the comparison carried out using one-way analysis of variance (ANOVA).

\section{RESULTS AND DISCUSSION}

\section{Polyphenol, Flavonoid and Tannin Contents}

In the present study, the quantification of total phenols was performed using Folin-Ciocalteu reagent. The results showed that ChE was the richest fractions on phenolic, flavonoids whereas; the ChE was the richest fractions on tannins, as shown in Table 1.

Table 1: Total polyphenol, a flavonoids and tannins content in A.scoparium extracts

\begin{tabular}{cccc}
\hline Extract & $\begin{array}{c}\text { Total phenolic } \\
\text { content } \mathbf{~ m g / G A E}\end{array}$ & $\begin{array}{c}\text { Total flavonoid } \\
\text { content mg/QE }\end{array}$ & $\begin{array}{c}\text { Total tannins content } \\
\text { mg/TAE }\end{array}$ \\
CrE & $18,00 \pm 3,54$ & $83,11 \pm 3.84$ & $93,63 \pm 2,65$ \\
ChE & $21,30 \pm 1,46$ & $95,94 \pm 2,81$ & $68,33 \pm 1,95$ \\
EAE & $3,83 \pm 1,361$ & $7,88 \pm 2,42$ & $51,77 \pm 0,48$ \\
AQE & $20,741 \pm 3,39$ & $19,61 \pm 1,18$ & $24,97 \pm 1,83$
\end{tabular}

Results are expressed as means \pm standard $(\mathrm{n}=3)$. CrE: crude extract, ChE: chloroform extract, EAE: ethyl acetate extract, AQE: aqueous extract, DEC: decoction, GAE: gallic acid equivalent, QE: quercitin equivalent, TAE: tannic acid equivalent.

The phenolic contents of A.scoparium in our study were higher than that of Atriplex halimus and Anabasis articulate, which belong to the same family, (Belyagoubi-Benhammou et al., 2014) ${ }^{18}$. The extraction procedures and solvents are responsible for dissolving the endogenous compound of the plants. Moreover, plant components can be polar or nonpolar in nature; due to the presence of a hydroxyl group, therefore methanol was selected as the extracting solvent (Kumar and Roy, 2018; Aryal et al., 2019) ${ }^{19,} 20$.

\section{Hydroxyl radical scavenging activity}

Hydroxyl radical is one of the potent reactive oxygen species. In the biological system, it reacts with polyunsaturated fatty acid of cell membrane and causes damage to cell. The studied extracts showed an important anti-radical effect, positively related to their amount of total phenolic and flavonoids contents. As shown in Fig.1 it was found that the CrE recorded the highest hydroxyl radical scavenging effect with $\mathrm{IC}_{50}=0.022 \pm 0.013 \mathrm{mg} / \mathrm{ml}$.

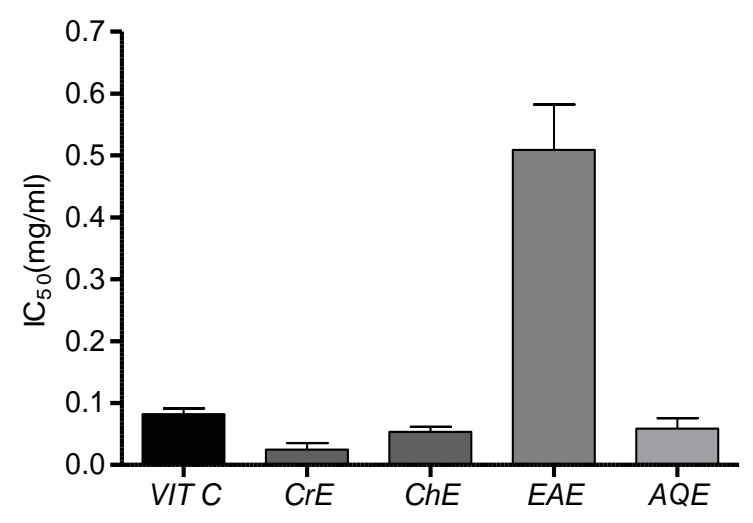

Figure 1: $\mathrm{IC}_{50}$ values of different plant extracts in hydroxyl radical scavenging activity. CrE: crude extract, ChE: chloroform extract, EAE: ethyl acetate extract, AQE: aqueous extract. Data were presented as IC $_{50}$ means \pm SD $(\mathrm{n}=3)$ compared to vitamin $\mathrm{C}$ as standard. 
The mainly function of hydroxyl radical as free radical scavengers, chain breaking antioxidants, metal chelators, reducing agents, oxidative enzyme inhibitors and quenchers of singlet oxygen ${ }^{21}$ (Tijani et al., 2018). The important antiradical effect is positively related to the amount of total phenolic and flavonoids contents and this might be due to their active hydrogen donor ability of hydroxyl substitution 22 (Lupu and Cremer, 2018).

\section{Hydrogen peroxide scavenging activity}

Hydrogen peroxide itself is not very reactive and it is a weak oxidizing agent that inactivates a few enzymes directly, but it can sometimes be toxic. As represented in Fig.2. Results showed that the strongest scavenging effects were registered with $\mathrm{CrE} \mathrm{IC}_{50}=0.31 \pm 0.03 \mathrm{mg} / \mathrm{ml}$.

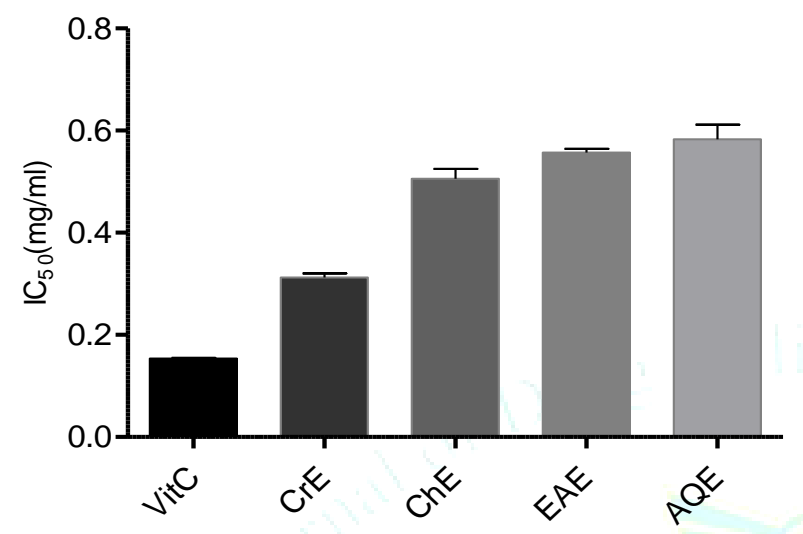

Figure 2: The $\mathrm{IC}_{50}$ values of $\mathrm{H}_{2} \mathrm{O}_{2}$ scavenging activity of A.scoparium. Values were expressed as mean \pm SD $(n=3)$. CrE: Crude extract, ChE: chloroform extract, EAE: ethyl acetate extract, $\mathrm{AQE}$ : aqueous extract. Data were presented as $\mathrm{IC}_{50}$ means $\pm \mathrm{SD}(\mathrm{n}=3)$ compared to vitamin $\mathrm{C}$ as standard.

According to literature, many studies demonstrate the positive relationship between total phenols and $\mathrm{H}_{2} \mathrm{O}_{2}$ scavenging activity, which appears to be the trend in many plant species ${ }^{23}$ (Ruskin et al., 2017). The present study revealed a significant correlation between both total phenols and flavonoids contents and $\mathrm{IC}_{50}$ of $\mathrm{H}_{2} \mathrm{O}_{2}$ scavenging activity, suggesting that phenolics compounds were responsible for this antioxidant activity.

\section{Assessment of in vitro anti-inflammatory activity \\ Inhibition of albumin denaturation}

A. scoparium extracts were able to inhibit protein denaturation in a dose-dependent manner. The inhibitory effect of different extracts at different concentrations on protein denaturation is shown in Fig.3. Inhibition percentage of protein denaturation of studied plant was ranging from 70 $\%$ to $97 \%$ using concentrations varying between 5 and 30 $\mathrm{mg} / \mathrm{ml}$. A. scoparium $\mathrm{CrE}$ exhibited a higher level of inhibition compared to other extracts.

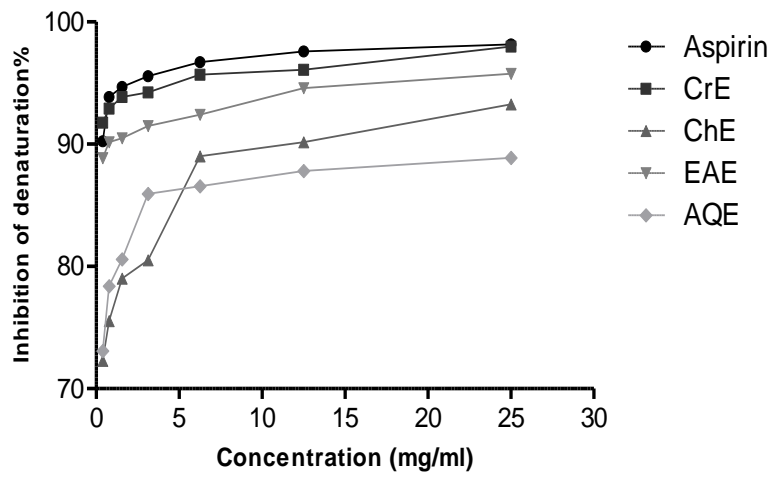

Figure 3: Effects of A.scoparium extracts on protein denaturation. CrE: Crude extract, ChE: chloroform extract, EAE: ethyl acetate extract, AQE: aqueous extract. Data are presented as the means \pm standard deviations of three replicate determinations.

\section{Egg albumin denaturation}

All $A$.scoparium extracts exhibited a significant antiinflammatory activity at diffrents dose as presented in Fig.4. The CrE $(5,15$ and $25 \mathrm{mg} / \mathrm{ml})$ exhibited the highest antiinflammatory effect similar with positive control.

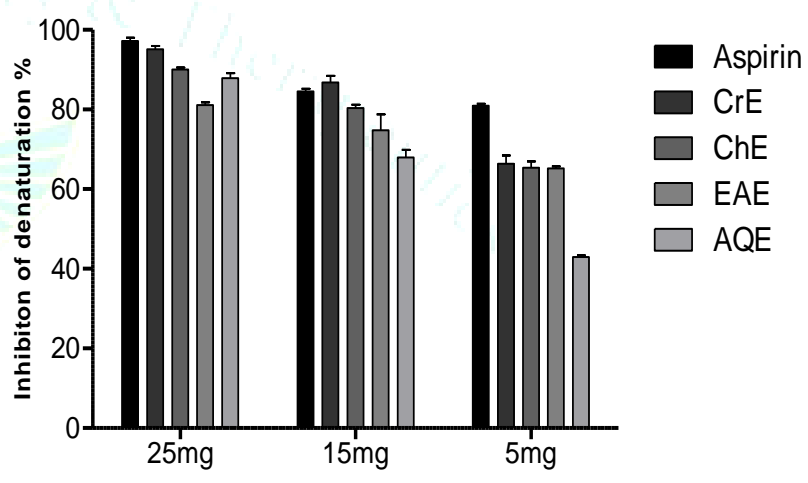

Figure 4: Influence of extracts of A.scoparium against protein denaturation. CrE: Crude extract, ChE: chloroform extract, EAE: ethyl acetate extract, AQE: aqueous extract. Data are presented as the means \pm standard deviations of three replicate determinations.

Denaturation of protein molecules is well documented in the literature, and it is due to an inflammation process in conditions like arthritis. One of the main mechanisms of action of NSAIDs is the protection against protein denaturation $^{24}$ (Gunathilake et al., 2018). Protein denaturation is a process in which proteins lose their tertiary structure and secondary structure by application of external stress or compound such as strong acid or base, a concentrated inorganic salt, an organic solvent, or heat. Most biological proteins lose their biological function when denatured 16 (Kiranmayi et al., 2018). The effect of different plant parts on protein denaturation have been evaluated by two methods (BSA and egg albumen). From the result illustrated in Fig.3 and Fig.4, it can be stated that all the extracts of A.scoparium are capable to inhibit the denaturation of proteins and their effect were comparable to standard drug. These effects are may be due to the presence of active principles in the extracts and/or polyphenolic content and flavonoids presents in various fractions 24 (Gunathilake et al., 2018). 


\section{Carrageenan induced paw edema}

Results in Fig.5 showed that 100, 200 and $400 \mathrm{mg} / \mathrm{kg}$ b.w. of $\mathrm{CrE}$ and $10 \mathrm{mg} / \mathrm{kg}$ b.w. Diclofenac Sodium treated animals induced with inflammation using carrageenan inhibited paw edema in a dose-dependent manner after a period of 6 hours. Data in Fig.6 indicated that diclofenac Sodium $(10 \mathrm{mg} / \mathrm{kg}$ b.w.) and $\mathrm{CrE}(400 \mathrm{mg} / \mathrm{kg}$ b.w.) suppressed paw edema of rats after sixth hour of the treatment by $86.74 \%$ and $87.02 \%$, respectively.
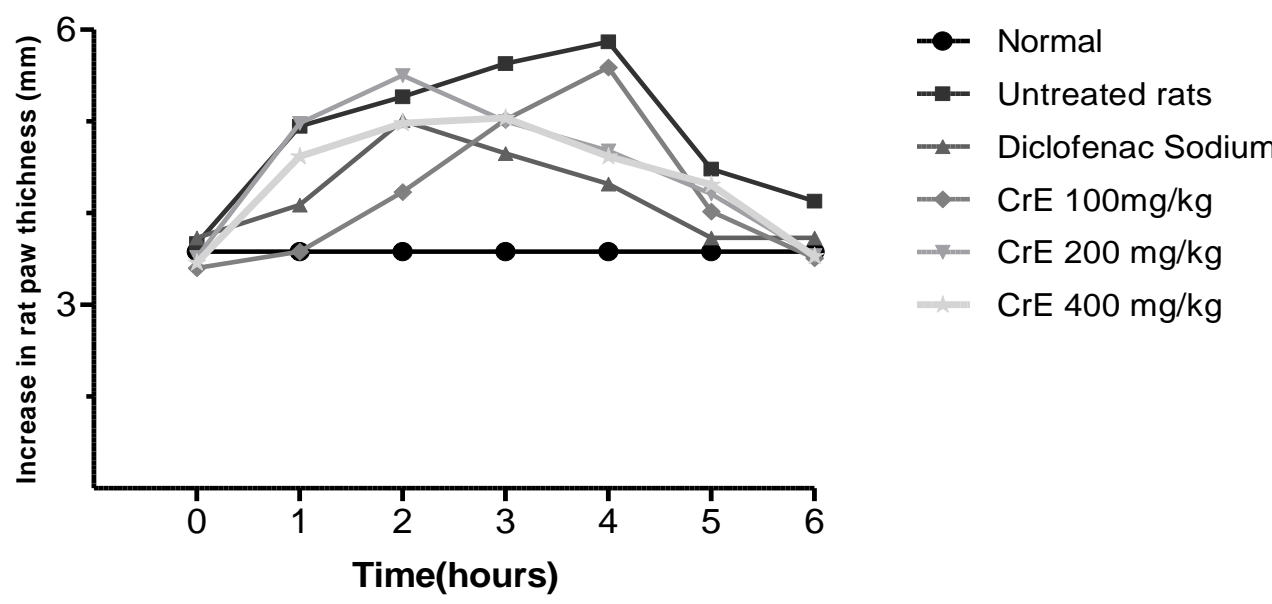

Figure 5: Change in paw edema by different doses of methanol extract of $\mathrm{CrE}$ in rat induced inflammation using carrageenan. Data expressed as mean \pm standard error of mean.

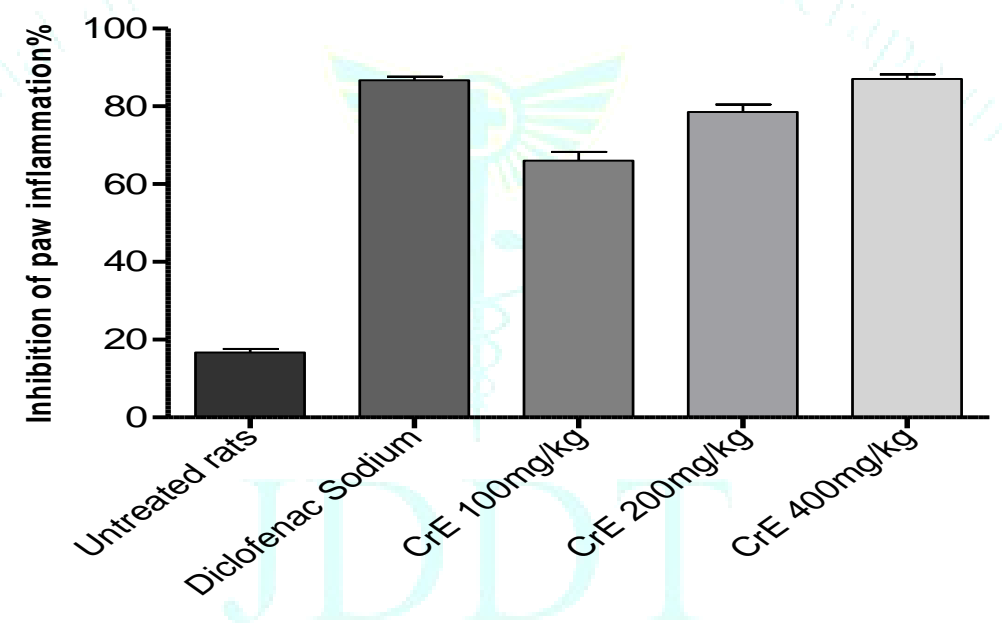

Figure 6: Percentage inhibition of carrageenan-induced paw edema in rats treated with different doses of CrE of A.scoparium. Data expressed as mean \pm standard error of mean.

For assessment of anti-inflammatory effect of natural products. Carrageenan-induced paw edema has been used widely as an animal model of inflammation and is divided into two phases 25 (Banerjee et al., 2014).The initial phase (1 $\mathrm{h}$ or $1.5 \mathrm{~h}$ ) is mainly a non-phagocytic edema and it involves the release of pro-inflammatory compounds, such as histamine and serotonin, while the late phase (up to $5 \mathrm{~h}$ ) is due to increased COX-2 and the release of $\mathrm{PGE}_{2}{ }^{17}$ (kim et al., 2018). Based on our results (Fig.5 and Fig.6), CrE reduced carrageenan-induced inflammation in the early phase. In the same time, it is effectively inhibited the increase of paw edema during the late phase of inflammation.

\section{CONCLUSION}

The present study demonstrates that all the extracts of Arthrophytum scoparium are a potential source of natural antioxidants and serves as an effective free radical scavenger. Our result clearly demonstrates that the extracts of Arthrophytum scoparium have anti-inflammatory activities in both in vitro and in vivo systems. Results of this study can accelerate the development of a new class of antiinflammatory agents and be a good plant-based pharmaceutical product for several diseases caused by free radicals. Further research on isolating the responsible components may be undertaken and they may be incorporated into existing anti-inflammatory herbal compositions to improve their efficacy.

\section{ACKNOWLEDGEMENTS}

The authors acknowledge the Algerian Ministry of Higher Education and Scientific Research (MESRS) and the General Directorate of Scientific Research and Technological Development (DGRSDT) for their financial support during the period of the research. 


\section{COMPETING INTERESTS}

Authors have declared that no competing interests exist

\section{REFERENCES}

1. Chen L, Deng $\mathrm{H}$, Cui $\mathrm{H}$ et al. Inflammatory responses and inflammation-associated diseases in organs. Oncotarget. 2017; 9(6):7204-7218.

2. Poovizhi A K, Monika S, Swapna N M, JeyavelKarthick P and Prabhu N. Analysis of anti-inflammatory avtivity in medicinal plants. Int J Recent Sci Res. 2019; 10(09):35039-35045.

3. Yuan H, Ma Q, Ye L and Piao G. The Traditional Medicine and Modern Medicine from Natural Products. Molecules.2016; 21:559.

4. Che T and Zhang. Plant Natural Products for Human Health. Int. J. Mol. Sci. 2019; 20:830.

5. Bailey-Shaw YA, Williams L A D, Green E C, Rodney S, Smith AM. In-Vitro Evaluation of the Anti-Inflammatory Potential of Selected Jamaican Plant Extracts using the Bovine Serum Albumin Protein Denaturation Assay. Int. J. Pharm. Sci. Rev. Res. 2017; 47(1):145-153, No. 27.

6. Oguntibeju 0 O. Medicinal plants with anti-inflammatory activities from selected countries and regions of Africa.J Inflamm Res.2018; 11:307-317.

7. Allaoui M, Cheriti A, Chebouat E, Dadamoussa B and Gherraf N. Comparative Study of the antioxidant activity andpheols and flavonoids contents of the ethyl acetate extracts from two saharan chenopodacea: Haloxylon scoparium AND Traganum nudatum. Algerian journal of arid environment, 2016; 6(1):7179.

8. Fatehi N, Allaoui M, Berbaoui H, Cheriti A, Boulenouar N, Belboukhari N. Haloxylon Scoparium: An Ethnopharmacological Survey, Phytochemical Screening and Antibacterial Activity against Human Pathogens Causing Nosocomial Infection. PhytoChem \& BioSub Journal. 2017; 11(2).

9. Madoui S, Charef N, Arrar L, Baghianni A and Khennouf S. In vitro Antioxidant Activities of Various Extracts from FlowersLeaves Mixture of Algerian Cytisus triflorus. Annu Res Rev Biol. 2018; 26(3):1-13.

10. Boussoualim N, Krache I, Baghiani A, Trabssa H, Aouchria S, Arrar L. Human xanthine oxidase inhibitory effect, antioxidant in vivo of Algerian extracts (Globularia alypum L.). J Pharmacogn Phytochem. 2016; 8(4):645-650.

11. Guemmaz T, Zerrargui F, Boumerfeg S, Arrar L, Aoucharia S, Khennouf S, Charef N, Baghiani A. Anti-hemolytic, Anti-lipid Peroxidation, Antioxidant Properties and Toxicity of Xanthium strumarium Leaves Extracts. Annu Res Rev Biol.2018; 24 (3):1-12

12. Bouaziz A, Khennouf S, Abdalla S, Djidel S, Abu Zarga M, Bentahar A, Dahamna S, Baghiani A, Amira S. Phytochemical Analysis, Antioxidant Activity and Hypotensive Effect of Algerian Azarole (Crataegus azarolus L.) Leaves Extracts. Res.J.
Pharm. Biol.Chem. Sci.2014; 8(6):968-976.

13. Mayouf N, Charef N, Saoudi S, Baghiani A, Khennouf S, Arrar L. Antioxidant and anti-inflammatory effect of Asphodelus microcarpus methanolic extracts. J. Ethnopharmacol. 2019; 239:111914.

14. Benslama A, Boumerfeg S, Aouachria S, Guemmaz T, Arrar L, Khennouf $S$ and Baghiani A. Xanthine Oxidase Inhibition, Invitro Antioxidant Activity and Antibacterial Effect of the Aerial Part Extracts of Thymus pallidus Coss. Curr Nutr Food Sci. 2019; 15:1-9.

15. Rastogi S, Iqbal M S, Ohri D. In vitro study of anti-inflammatory and antioxidant activity of some medicinal plants and their interrelationship. Asian J Pharm Clin Res.2018; 11(4):195202.

16. Kiranmayi G V N, Anusha V, Chandrika Y, Satya Priya I V, Santhu Swetha K U B G, Vamsi Krishna Y. Preliminary phytochemical screening and in vitro evaluation of antiinflammatory, antiarthritic, and thrombolytic activities of ethanolic leaf extract of Bauhinia purpurea. Int. J. Green Pharm.2018; 12(1):S241.

17. Kim J, Kim H, Choi $\mathrm{H}$ et al. Anti-Inflammatory Effects of a Stauntonia hexaphylla Fruit Extract in LipopolysaccharideActivated RAW-264.7 Macrophages and Rats by CarrageenanInduced Hind Paw Swelling. Nutrients.2018; 10(1):110.

18. Belyagoubi-Benhammou $\mathrm{N}$ et al. (Phenolic content and antioxidant activities in vitro of some selected Algerians plants. J Med Plant Res. 2014; 8(40):1198-1207.

19. Kumar V, Roy B K. Population authentication of the traditional medicinal plant Cassia tora L. based on ISSR markers and FTIR analysis. Sci. Rep.2018; 8, 10714.

20. Aryal S, Baniya MK, Danekhu K, Kunwar P, Gurung R, Koirala N. Total Phenolic Content, Flavonoid Content and Antioxidant Potential of Wild Vegetables from Western Nepal. Plants (Basel). 2019; 8(4):96.

21. Tijani A A, Adekomi D A, Adewole S O. In vitro and in vivo Determination of Hydroxyl Radical Scavenging Activity (HRSA) of Fractions of Aqueous Extract of Moringa Oleifera Leaves (AEMOL). Eurasian J Med Oncol. 2018; 2(4):209-216.

22. Lupu A R and Cremer L. Hydroxyl radical scanenger activity of natural sod. Roum Arch Microbiol Immunol.2018; 77(1):7383.

23. Ruskin R, Vasanthakumari $B$ and Citarasu T. In vitro antioxidant activity of various leaf extracts of canthium coromandelicum (Burm.f.) Alston. Asian J Pharm Clin Res.2017; 10:214-218.

24. Gunathilake K D P P, Ranaweera K K D S and Vasantha Rupasinghe H P. In Vitro Anti-Inflammatory Properties of Selected Green Leafy Vegetables. Biomedicine.2018; 6:107.

25. Banerjee S, Chanda A, Adhikari A, Das A, Biswas S. Evaluation of Phytochemical Screening and Anti Inflammatory Activity of Leaves and Stem of Mikania scandens (L.) Wild. Ann Med Health Sci Res. 2014; 4(4):532-536. 